$\underline{\xi}=-m$

\title{
Pharmacokinetics of clarithromycin after single intravenous and intracrop bolus administrations to broiler chickens
}

\author{
Hanady Awadallah ${ }^{1}$, Shaban Awidat ${ }^{1}$, Abubakr El-Mahmoudy ${ }^{2} *$ \\ ${ }^{1}$ Department of Pharmacology, Toxicology and Forensic Medicine, Faculty of Veterinary Medicine, \\ University of Tripoli, 13662 Tripoli, Libya \\ ${ }^{2}$ Department of Pharmacology, Faculty of Veterinary Medicine, Benha University, 13736 Moshtohor, Egypt \\ *Corresponding author E-mail: a.elmahmoudy@fvtm.bu.edu.eg
}

\begin{abstract}
The pharmacokinetics of clarithromycin at a dose of $7.5 \mathrm{mg} / \mathrm{kg}$ body weight was evaluated after single intravenous (i.v.) and intracrop (i.c.) bolus administrations in broilers. An HPLC assay using pure clarithromycin base as a standard was used to measure its concentrations in plasma. Following an i.v. bolus injection, the plasma concentration-time curves of clarithromycin were best represented by twocompartment open models. The drug was rapidly distributed and moderately eliminated with half-lives of distribution $\left(t_{1 / 2 \alpha}\right)$ and elimination $\left(t_{1 / 2 \beta}\right)$ of 0.38 and $4.58 \mathrm{~h}$, respectively. The volume of distribution was large with $\left(\mathrm{V}_{\mathrm{dss}}\right)$ value of $6.89 \mathrm{~L}$. The total body clearance $\left(C l_{\mathrm{B}}\right)$ was $1.2 \mathrm{~L} / \mathrm{h}$. After i.c. bolus administration of the same dose, clarithromycin was moderately absorbed in broilers with an intermediate absorption half-life $\left(T_{1 / 2 a b}\right)$ of $0.72 \mathrm{~h}$ with peak plasma concentration $\left(C_{\max }\right)$ of $1.69 \mu \mathrm{g} / \mathrm{ml}$ attained at $1.7 \mathrm{~h}\left(T_{\max }\right)$ and systemic bioavailability of $66.54 \%$. The elimination half-life following i.c. administration was $2.11 \mathrm{~h}$. The extent of plasma protein binding percent was $52 \%$. The study recommends the use of clarithromycin in broilers because of its good pharmacokinetic profile indicated by good absorption, bioavailability and plasma concentrations $\geq$ MICs of many sensitive microorganisms.
\end{abstract}

Keywords: Broiler; Chicken; Clarithromycin; Intracrop; Intravenous; Pharmacokinetics.

\section{Introduction}

Bacterial infections may be life threatening or cause great economic losses in human being and animals; antibacterial intervention is therefore a critical issue. However, developing resistant bacterial strains remain a constant medical problem due to the frequent use of classical antibiotics. Introducing new antibacterial agents may solve such problem. Clarithromycin is a semisynthetic erythromycin-derivative, macrolide antibiotic. It exerts its antibacterial action by binding to the $50 \mathrm{~S}$ ribosomal subunits of susceptible bacteria with subsequent suppression of protein synthesis. It is highly potent against a wide variety of aerobic and anaerobic Gram-positive and Gram-negative organisms, including Mycobacteria, Helicobacter, Mycoplasma, Chlamydia, Legionella, Clostridia \& Staphylococci.

Clarithromycin differs in chemical structure (Fig. 1) from erythromycin by the methylation of the hydroxyl group at position 6 on the lactone ring. The pharmacokinetic advantages that clarithromycin has over erythromycin include increased oral bioavailability (52 to 55\%), increased plasma concentrations (mean maximum concentrations ranged from 1.01 to $1.52 \mathrm{mg} / \mathrm{L}$ and 2.41 to 2.85 $\mathrm{mg} / \mathrm{L}$ after multiple 250 and $500 \mathrm{mg}$ doses, respectively), and a longer elimination half-life (3.3 to 4.9 hours) to allow twice daily administration (Rodvold 1999). Because of its numerous advantages over erythromycin, clarithromycin is an attractive alternative for the treatment of violent bacterial strains in veterinary medicine. However, the lack of pharmacokinetic studies precludes the rational use of this antimicrobial agent in targeted animal species. Pharmacokinetics of clarithromycin has been studied in human being (Ferrero et al. 1990), (Chu et al. 1992a) (Traunmuller et al. 2007), desert tortoise (Wimsatt et al. 1999); foals (Jacks et al. 2002), beagle dogs (Zhang et al. 2008) and cats (Katayama et al. 2012).

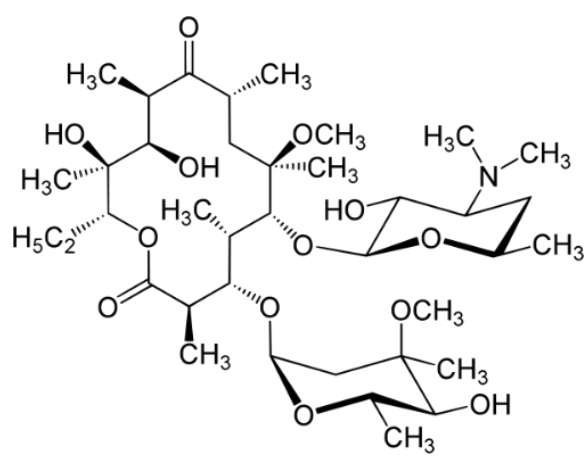

Fig. 1: Structural Formula of Clarithromycin.

The present study was designed to characterize pharmacokinetic profile of clarithromycin in a not-yet-studied animal species that is broiler chickens after single intravenous (i.v.) bolus and single oral (intracrop, i.c.) administrations.

\section{Material \& methods}

\subsection{Study design}

In the present study, experiments I \& II were performed as randomized parallel study as described by (Grizzle 1965). Each 
chicken received clarithromycin either single dose intravenously (Experiment I) or single dose orally (Experiment II).

\subsection{The drug}

The standard clarithromycin base (purity 99.99\%) was obtained from Sigma Pharmaceuticals, Quesna, Egypt. It was used for standardization of calibration curve in HPLC and for i.v. experiment. It was dissolved with limit of $33 \mathrm{mg} / \mathrm{ml}$ acetone for experimental i.v. injection. Clarithromycin oral preparation was obtained as $\mathrm{Klacid}^{\circledR}$ powder for oral suspension $(250 \mathrm{mg} / 5 \mathrm{ml}$ after reconstitution; Abott Laboratories, UK). It was used for single oral pharmacokinetic study. The drug has the chemical name: 6-Omethylerythromycin; with molecular formula: $\mathrm{C}_{38} \mathrm{H}_{69} \mathrm{NO}_{13}$; and of molecular weight: 47.96. The dose given to each chicken was adjusted to $7.5 \mathrm{mg} / \mathrm{Kg}$ of body weight.

\subsection{Experimental animals}

Twenty four healthy, 40 day old, Ross broiler chickens with body weights of about $2 \mathrm{Kg}$ were used. Animals were numbered and accommodated in a suitable pen under hygienic condition with controlled temperature $\left(22 \pm 1^{\circ} \mathrm{C}\right)$, humidity $(60 \pm 10 \%)$ and light (12 $\mathrm{h}$ per day) for at least a week before being used. Food and water were available ad libitum. Six birds were used for Experiment-I, another six were used for Experiment-II, and the rest of birds were used for separation of clear plasma.

\subsection{Drug administration}

In the first experiment (Group I), animals were numbered as 1-6, and received $7.5 \mathrm{mg} / \mathrm{Kg}$ dose as a single i.v. bolus into the wing vein. In the second experiment (Group II), animals were numbered as $7-12$, and received $7.5 \mathrm{mg} / \mathrm{Kg}$ dose as a single oral bolus after 6 $\mathrm{h}$ of fasting; feed \& water were allowed $2 \mathrm{~h}$ post-administration.

\subsection{Duration of blood sample collection}

In the present study, it was decided to continue sampling until 12 hours. Five-mL lithium heparinised vacationer tubes and disposable $3 \mathrm{~mL}$ syringes with $23 \mathrm{G}$ needles were used for collection of 2 $\mathrm{mL}$ of blood at each bleeding point at the following intervals (h): $0.083,0.167,0.25,0.5,1,2,4,6,8,12$ (Experiment-I) and 0.5, 1 , 2, 4, 6, 8, 12 (Experiment-II). Two sites for sampling were used: Basilic vein (wing vein) that is located over the medial surface of the proximal ulna, and is more convenient for injection rather than sampling as it is much more prone to hematoma, so it was avoided for repeated sampling; and metatarsal vein that is located above the metatarsus and tibiometatarsal joint (hock) on the median side of the leg, it was preferred for repeated sampling.

\subsection{Clarithromycin HPLC assay}

i) Standard calibration curve

The calibration curves of plasma were prepared with seven different concentrations ranging between 0.125 and $8 \mu \mathrm{g} / \mathrm{mL}$ using blank chicken plasma. Clarithromycin reference substance equivalent to $50 \mathrm{mg}$ of clarithromycin was accurately weighed and transferred to a $50 \mathrm{~mL}$ volumetric flask. Methanol was added to make up volume in order to give a final concentration of $1 \mathrm{mg} / \mathrm{mL}$. From this solution, the stock concentration of $8000 \mathrm{ng} / \mathrm{mL}(8$ $\mu \mathrm{g} / \mathrm{mL}$ ) in blank plasma was prepared and aliquots of this stock were diluted with the blank plasma to obtain various concentrations of 4000, 2000, 1000, 500, 250 and $125 \mathrm{ng} / \mathrm{mL}(4,2,1,0.5$, $0.25,0.125 \mu \mathrm{g} / \mathrm{mL}$ ), which were assayed by HPLC using the method described below (the same method followed for samples). A calibration curve was obtained by plotting the peak heights versus the nominal concentrations. The equation was calculated by the least-squares method using linear regression. Under our experimental conditions, the linearity of the method was from 0.01 to $10 \mu \mathrm{g} / \mathrm{mL}$ of clarithromycin chicken plasma, and the value of cor- relation coefficients (r) was $>0.99$. The peak heights of clarithromycin in an unknown specimen were compared with those of the standard.

ii) Sample preparation for chromatography

The blood samples were centrifuged for 10 minutes at a speed of $1000 \mathrm{~g}$. The plasma was then separated from the cellular component by means of automatic pipettes. A new tip was used for every sample. The plasma samples were then placed in polyurethane Eppendorf tubes in which they are kept at $-50{ }^{\circ} \mathrm{C}$ until analysed by high performance liquid chromatography (HPLC).

The analytical HPLC procedure for determination of clarithromycin in plasma was adopted according to the method presented by (Amini and Ahmadiani 2005). Twenty $\mu 1$ of $1 \mathrm{~N} \mathrm{NaOH}$ were added to $1 \mathrm{~mL}$ of plasma. The mixture was extracted with $2.5 \mathrm{~mL}$ hexane: isopropyl alcohol (98: $2 \% \mathrm{v} / \mathrm{v})$ by vortexing for $5 \mathrm{~min}$. After centrifugation for $5 \mathrm{~min}$ at $1000 \mathrm{~g}$, the upper organic phase was transferred to a $5 \mathrm{~mL}$ glass tube and $100 \mu \mathrm{l}$ of $0.2 \%$ acetic acid was added. The mixture was vortex-mixed for $2 \mathrm{~min}$ and then part of the upper organic phase was discarded and the remaining mixture (about $1 \mathrm{~mL}$ ) transferred into a $1.5 \mathrm{~mL}$ micro-centrifuge tube. After centrifugation for $2 \mathrm{~min}$, the upper organic phase was discarded completely. The aqueous phase was then filtered and transferred into HPLC sample tubes; the injection volume was adjusted to $50 \mu 1$ taken automatically by autosampler.

iii) High performance liquid chromatography

The liquid chromatographic system used in the present study was Knauer $^{\circledR}$ (Berlin, Germany) consisted of a pump (Smartline Pump 1000 ) with solvent delivery module (Smartline Manager 5000) equipped with an autosampler (Smartline Autosampler 3950), analytical column (Eurospher 100-5 C18; $250 \times 4.6 \mathrm{~mm}$ ) with a thermostat (Smartline Column Thermostat; from 5 to $85^{\circ} \mathrm{C}$ ) and a variable wavelength ultraviolet detector (Smartline UV Detector 2600). ChromGate ${ }^{\circledR}$ v.3.3.2 chromatography software was used for data acquisition, data reporting and analysis. The mobile phase consisted of acetonitrile and $50 \mathrm{mM}$ aqueous sodium dihydrogen phosphate (32: 68\%, v/v), with $\mathrm{pH}=4.5$ (adjusted with concentrated phosphoric acid and $4 \mathrm{M}$ sodium hydroxide). The flow rate was $1 \mathrm{~mL} / \mathrm{min}$ at $40^{\circ} \mathrm{C}$; the sample injection volume was $50 \mu \mathrm{L}$; and the detector wavelength was set at $205 \mathrm{~nm}$. Under these conditions, the retention time for clarithromycin was 7.05 7.1 min. All plasma samples taken from each animal were analysed in the same chromatographic run (analytical own control). Each run had a separate daily calibration.

\subsection{Plasma protein binding assay}

The extent of plasma protein binding was determined in vitro using ultrafiltration according to the method described by (Craig and Suh 1991). Antimicrobial-free plasma from broiler chicken fortified with known concentrations of clarithromycin (1,2 and 4 $\mu \mathrm{g} / \mathrm{mL}$ ) was used. One $\mathrm{ml}$ of each sample was placed on a conditioned semipermeable membrane (Centriflow Cones CF-50, Amicon Corp., Lexington, MA, USA) resting on porous conical polyethylene support on the top of centrifuge tubes. The tubes were centrifuged at $1500 \mathrm{~g}$ for $60 \mathrm{~min}$. Plasma samples and their corresponding ultra-filtrates were assayed by the same HPLC method as described above. The percentage of plasma protein binding was calculated according to the following equation:

Protein binding $=\frac{\text { Total conc }- \text { Ultrafiltrate conc. }}{\text { Total conc } .} \times 100$

\subsection{Pharmacokinetic analysis}

Pharmacokinetic parameters were derived from concentration vs time (C-T) curves obtained from the experimental concentrations obtained individually for each animal, and reported as mean \pm SEM. Compartmental modelling of the drug C-T data was analysed.

i) Single intravenous bolus 
The plot of plasma C-T was fit to two-compartment open model that has been described by (Riegelman et al. 1968). This was on the basis of that the C-T curve was described by a bi-exponential equation and cannot be converted to a single straight line by converting plasma concentrations to the logarithmic domain as in occasion of one compartment open model. As simple linear regression cannot be used to estimate the parameters of the twocompartment model, the plasma C-T data were then linearized as two straight lines using a process called curve stripping (also known as the method of residuals or feathering) according to (Riggs 1964). The pharmacokinetic parameters were calculated according to equations integrated by (Baggot 1977), (Baggot 1978a), (Baggot 1978b) and (Rosenbaum 2012). The basic equation for the two-compartment model is:

$C_{p(t)}=A e^{-\alpha t}+B e^{-\beta t}$

Where, $\mathrm{C}_{\mathrm{p}(\mathrm{t})}$ is the concentration of drug in the plasma at a specified time $\mathrm{t} ; \alpha$ and $\beta$ are both hybrid rate constants; A \& B are constant terms of A given by Y-intercepts.

The process of curve stripping can isolate the two-component exponential functions to allow "A and $\alpha$ " and "B and $\beta$ " to be determined from straight lines obtained from semi-logarithmic plots. Then, the micro rate constants $\left(\mathrm{K}_{12}, \mathrm{~K}_{21} \& \mathrm{~K}_{10}\right)$ and the rest of pharmacokinetic parameters including, $\left(\mathrm{t}_{1 / 2 \alpha}\right),\left(\mathrm{t}_{1 / 2 \beta}\right), \mathrm{V}_{\mathrm{d}(\mathrm{c})}, \mathrm{V}_{\mathrm{d}(\beta)}$, and $\mathrm{V}_{\mathrm{d}(\mathrm{ss})},\left(\mathrm{Cl}_{\mathrm{B}}\right)$ and $\left(\mathrm{Cl}_{\mathrm{d}}\right)$ were calculated from these four parameters.

ii) Single intracrop bolus

In this occasion the drug was not administered directly to the systemic circulation. Therefore, access of the drug to the blood from its site of administration (absorption) was a must. The process of absorption brings two additional parameters into the pharmacokinetic model: the bioavailability factor $(F)$ and a parameter for the rate of drug absorption, the first-order absorption rate constant $\left(\mathrm{K}_{\mathrm{ab}}\right)$.

The plasma concentration at any time after the i.c. dose can be described by the following bi-exponential equation:

$$
C_{p(t)}=\frac{F * D * K_{a b}}{V_{d} *\left(K_{a b}-K_{e l}\right)} *\left(e^{-K_{e l} * t}-e^{-K_{a b} * t}\right)
$$

This basic equation is bi-exponential and its curve has not been made linear by transforming the data to the logarithmic scale. Therefore, the parameters have been obtained by linearizing the data through curve stripping. The first-order elimination rate constant $\left(\mathrm{K}_{\mathrm{el}}\right)$, elimination half-life $\left(\mathrm{t}_{1 / 2(\mathrm{el})}\right)$, first-order absorption rate constant $\left(\mathrm{K}_{\mathrm{ab}}\right)$, absorption half-life $\left(\mathrm{t}_{1 / 2(\mathrm{ab})}\right)$ and $\mathrm{Y}$-intercept were initially determined and the rest of parameters were then derived.

The presence of a peak in the plasma C-T profile is a characteristic for oral and other extravascular administrations. The peak can be summarized by the value of the peak plasma concentration $\left(\mathrm{C}_{\max }\right)$ and the time at which it occurs $\left(\mathrm{T}_{\max }\right)$. These two metrics can have an important influence on the drug response. The $T_{\max }$ can control the onset of action of the drug, and $\mathrm{C}_{\max }$ may determine if the dose is sub-therapeutic, therapeutic, or toxic.

\subsection{Statistical analysis}

HPLC analysis of clarithromycin standard concentrations were done as triplicates; and mean standard error values were used. Concentrations of clarithromycin in time point plasma samples were calculated as Mean \pm SEM of six observations $(n=6)$ and C$\mathrm{T}$ tables and graphs were designed using these values. Each pharmacokinetic parameter was calculated for every individual animal; and the final data were expressed as Mean \pm SEM of 6 observations $(n=6)$ in each experimental group (single oral bolus; single intravenous bolus) included in the study. All statistical procedure were done using SPSS software.

\section{Results}

No clinical toxicity symptoms appeared on clarithromycinadministered birds. Just only some drowsiness for a few seconds was observed after i.v. administration.

\subsection{Standard calibration curve}

Figs. 2, 3 and 4 are examples of recorded chromatograms showing the peaks of absorbance (indicated by arrows) of the standard concentrations $(1,2 \& 4 \mu \mathrm{g} / \mathrm{mL})$ of clarithromycin in drug-free broiler chicken plasma.

Fig. 5 shows the standard curve of clarithromycin in drug-free plasma obtained by depicting all used concentrations from 0.125 to $8 \mu \mathrm{g} / \mathrm{mL}$.

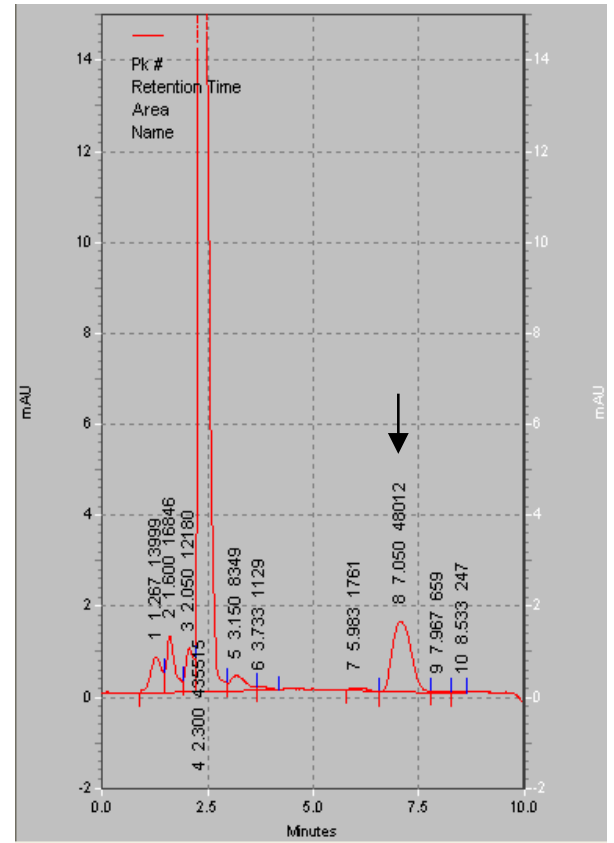

Fig. 2: Chromatogram Showing Peak of Absorbance (Indicated by Arrow) of the Standard Concentration $(1 \mu \mathrm{g} / \mathrm{Ml})$ of Clarithromycin in Drug -Free Broiler Chicken Plasma.

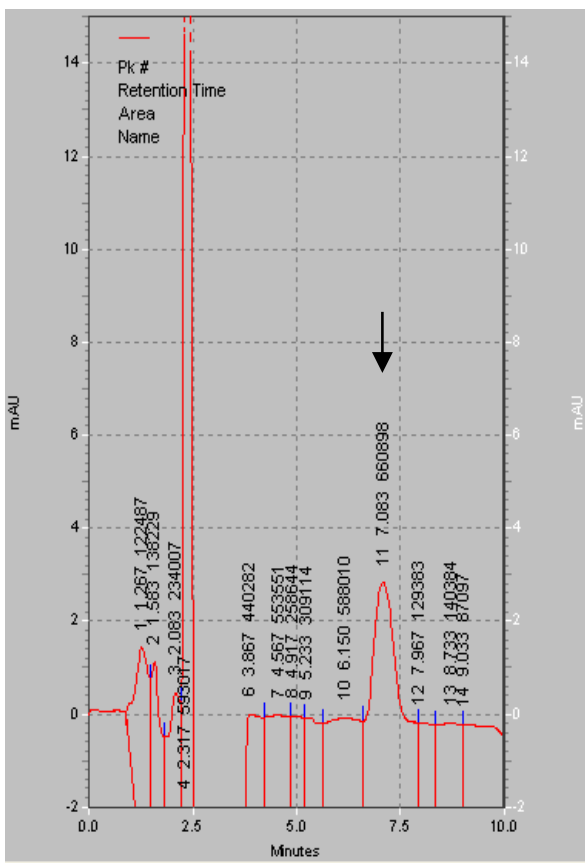

Fig. 3: Chromatogram Showing Peak of Absorbance (Indicated by Arrow) of the Standard Concentration $(2 \mu \mathrm{g} / \mathrm{Ml})$ of Clarithromycin in Drug-Free Broiler Chicken Plasma. 


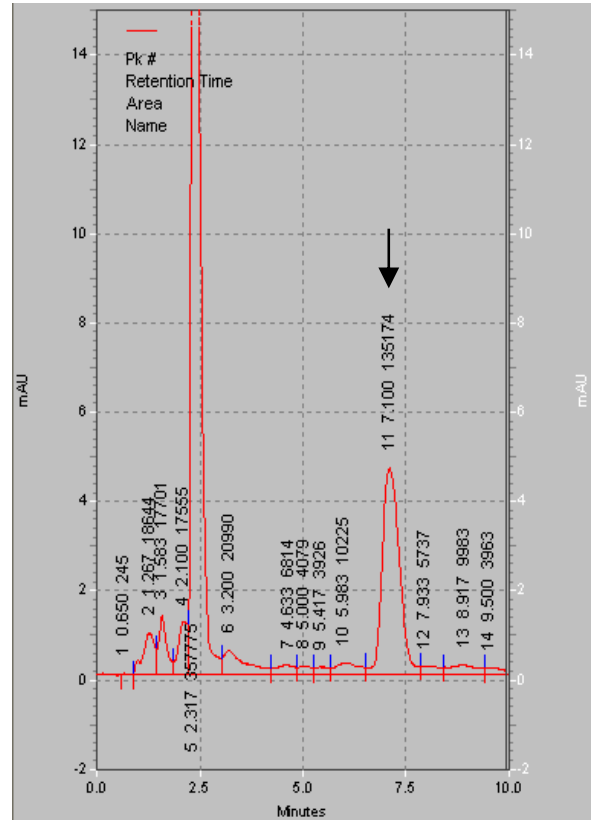

Fig. 4: Chromatogram Showing Peak of Absorbance (Indicated by Arrow) of the Standard Concentration $(4 \mu \mathrm{g} / \mathrm{Ml})$ of Clarithromycin in Drug-Free Broiler Chicken Plasma.

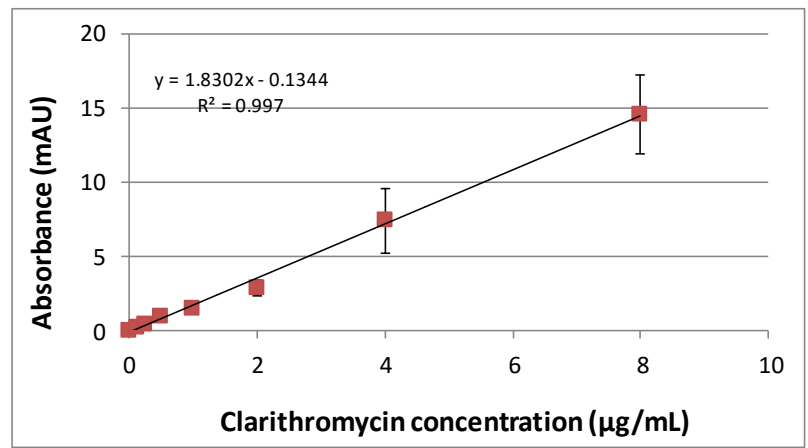

Fig. 5: Histogram Showing Standard Curve of Clarithromycin in DrugFree Broiler Chicken Plasma. Values are expressed as Means and Standard Errors of the Means of Triplicates.

\subsection{Plasma concentrations}

Table 1 and Fig. 5 show Mean \pm SEM values of plasma concentration $(\mu \mathrm{g} / \mathrm{mL})$ of clarithromycin following single i.v. and i.c. bolus administrations at dose rate of $7.5 \mathrm{mg} / \mathrm{Kg}$ body weight in broiler chickens $(n=6)$.

Table 1: Clarithromycin Plasma Concentrations ( $\mu \mathrm{g} / \mathrm{Ml})$ after Single I.V and I.C $7.5 \mathrm{Mg} / \mathrm{Kg}$ B Wt Bolus Administrations to Broiler Chickens.

\begin{tabular}{lll}
\hline Time $(\mathrm{h})$ & $\mathrm{C}_{\mathrm{p}}(\mu \mathrm{g} / \mathrm{mL})$ after i.v. & $\mathrm{C}_{\mathrm{p}}(\mu \mathrm{g} / \mathrm{mL})$ after i.c. \\
\hline 0.083 & $5.056 \pm 0.505$ & $\mathrm{NM}$ \\
0.167 & $4.230 \pm 0.337$ & $\mathrm{NM}$ \\
0.25 & $3.440 \pm 0.201$ & $\mathrm{NM}$ \\
0.5 & $2.731 \pm 0.149$ & $0.694 \pm 0.080$ \\
1 & $2.103 \pm 0.129$ & $1.346 \pm 0.136$ \\
2 & $1.528 \pm 0.099$ & $1.637 \pm 0.077$ \\
4 & $0.886 \pm 0.084$ & $1.076 \pm 0.085$ \\
6 & $0.533 \pm 0.064$ & $0.621 \pm 0.068$ \\
8 & $0.321 \pm 0.043$ & $0.332 \pm 0.050$ \\
12 & $0.127 \pm 0.022$ & $0.092 \pm 0.023$ \\
\hline
\end{tabular}

NM: not measured.

\subsection{Pharmacokinetic parameters}

Pharmacokinetic parameters of clarithromycin in broiler chickens following single i.v. and i.c. bolus administrations of $7.5 \mathrm{mg} / \mathrm{Kg}$ body weight respectively are listed in Table $2 \& 3$.

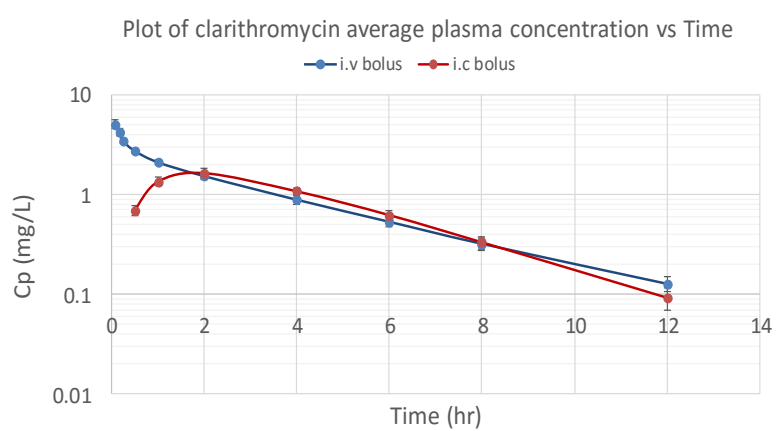

Fig. 5: Logarithmic Plot Showing Plasma Concentrations of Clarithromycin after I.V and I.C Single Bolus Administrations to Broilers along Time Course Up to $12 \mathrm{H}$. Values are Expressed as means and Standard Errors of the Means of 6 Observations.

Table 2: Pharmacokinetic Parameters of Clarithromycin in Broiler Chickens Following A Single I.V. Bolus Administration of $7.5 \mathrm{Mg} / \mathrm{Kg} \mathrm{B} \mathrm{Wt} \mathrm{(N}$ $=6)$.

\begin{tabular}{ll}
\hline Parameter (unit) & Value $($ Mean \pm SEM) \\
\hline$\beta\left(\mathrm{hr}^{-1}\right)$ & $0.155 \pm 0.689$ \\
$\mathrm{~B}(\mathrm{mg} / \mathrm{L})$ & $1.815 \pm 0.174$ \\
$\alpha\left(\mathrm{hr} r^{-1}\right)$ & $1.958 \pm 0.252$ \\
$\mathrm{~A}(\mathrm{mg} / \mathrm{L})$ & $3.246 \pm 0.297$ \\
$\mathrm{C}^{\circ}(\mathrm{mg} / \mathrm{L})$ & $5.062 \pm 0.411$ \\
$\mathrm{~T}^{1 / 2 \alpha}(\mathrm{hr})$ & $0.383 \pm 0.046$ \\
$\mathrm{~T}^{1} / 2 \beta(\mathrm{hr})$ & $4.584 \pm 0.359$ \\
$\left.\mathrm{~K}_{12}(\mathrm{hr})^{-1}\right)$ & $0.931 \pm 0.152$ \\
$\mathrm{~K}_{21}\left(\mathrm{hr} r^{-1}\right)$ & $0.804 \pm 0.099$ \\
$\mathrm{~K}_{10}\left(\mathrm{hr} r^{-1}\right)$ & $0.378 \pm 0.023$ \\
$\mathrm{AUC}(\mathrm{mg} \cdot \mathrm{hr} / \mathrm{L})$ & $13.62 \pm 1.230$ \\
$\mathrm{~V}_{\mathrm{c}}(\mathrm{L})$ & $3.216 \pm 0.222$ \\
$\mathrm{~V}_{\beta}(\mathrm{L})$ & $7.867 \pm 0.637$ \\
$\mathrm{~V}_{\mathrm{d}(\mathrm{ss})}(\mathrm{L})$ & $6.893 \pm 0.495$ \\
$\mathrm{Cl}_{\mathrm{B}}(\mathrm{L} / \mathrm{hr})$ & $1.200 \pm 0.083$ \\
$\mathrm{Cl}_{\mathrm{d}}(\mathrm{L} / \mathrm{hr})$ & $2.849 \pm 0.305$ \\
$\mathrm{~V}_{\mathrm{t}}(\mathrm{L})$ & $3.677 \pm 0.348$ \\
\hline
\end{tabular}

Table 3: Pharmacokinetic Parameters of Clarithromycin in Broiler Chickens Following A Single I.C. Bolus Administration of $7.5 \mathrm{Mg} / \mathrm{Kg} \mathrm{B} \mathrm{Wt} \mathrm{(N}$ $=6)$.

\begin{tabular}{ll}
\hline Parameter (unit) & Value (Mean \pm SEM) \\
\hline$\beta\left(\mathrm{hr}^{-1}\right)$ & $0.343 \pm 0.032$ \\
$\mathrm{~B}(\mathrm{mg} / \mathrm{L})$ & $5.128 \pm 3.059$ \\
$\alpha\left(\mathrm{hr}^{-1}\right)$ & $0.998 \pm 0.085$ \\
$\mathrm{~A}(\mathrm{mg} / \mathrm{L})$ & $5.425 \pm 1.047$ \\
$\mathrm{I}_{\mathrm{B}}(\mathrm{mg} / \mathrm{L})$ & $5.128 \pm 1.035$ \\
$\mathrm{~T}_{1 / 2 \mathrm{ab}}(\mathrm{hr})$ & $0.718 \pm 0.057$ \\
$\mathrm{~T}_{1 / 2 \mathrm{el}}(\mathrm{hr})$ & $2.105 \pm 0.186$ \\
$\mathrm{~K}_{\mathrm{ab}}\left(\mathrm{hr}{ }^{-1}\right)$ & $0.998 \pm 0.085$ \\
$\mathrm{~K}_{\mathrm{el}}\left(\mathrm{hr}{ }^{-1}\right)$ & $0.343 \pm 0.032$ \\
$\mathrm{AUC}(\mathrm{mg} \cdot \mathrm{hr} / \mathrm{L})$ & $8.970 \pm 0.707$ \\
$\mathrm{~F}(\%)$ & $66.54 \pm 3.404$ \\
$\mathrm{~V}_{\mathrm{d}}(\mathrm{L})$ & $3.592 \pm 0.294$ \\
$\mathrm{Cl}_{\mathrm{B}}(\mathrm{L} / \mathrm{hr})$ & $1.200 \pm 0.084$ \\
$\mathrm{~T}_{\max }(\mathrm{hr})$ & $1.662 \pm 0.074$ \\
$\mathrm{C}_{\max }(\mathrm{mg} / \mathrm{L})$ & $1.691 \pm 0.072$ \\
\hline
\end{tabular}

\section{Discussion}

The importance of pharmacokinetic studies is centred in the characterisation of the time course of drug absorption, distribution, biotransformation and excretion. These processes orchestrate the intensity and duration of effects of drugs (Baggot 1995). To produce its characteristic effect, a drug must attain effective concentrations at its site of action.

In veterinary medicine, the need of pharmacokinetics is further complicated by the variety of animal species to which therapeutic agents are administered. Wide variations in intensity and duration of pharmacologic effects are commonly observed among species of domestic animals when a drug is given at the same dose and dosage (Baggot 1995). 
Clinical pharmacological studies mainly support the view that species variations in response to drugs are attributed to differences in one of the following processes: systemic availability, accessibility to the site of action and the rate of elimination, including biotransformation and excretion (Dorrestein 1991). When a drug is administered by the oral route, the rate and extent of its absorption from the gastro-intestinal tract are likely to vary between the species based on the anatomical and physiological differences in gastro-intestinal system. Similarly, the rate and extent of drug elimination vary among species based anatomical and physiological differences in the renal system among different species. In addition, capacity and rate of biotransformation, and thus elimination, are vastly different due to the differences in liver microsomal enzyme activities among species. Poultry in general have a relatively less capacity than mammals; and in particular, they are deficient in gucuronide conjugation phase-II reactions (Watkins and Klaassen 1986).

Macrolide antimicrobial agents are chemically comprised of a lactone ring with $13,14,15$ or 16 carbons attached to 2 sugar moieties.

Macrolides can inhibit protein synthesis by reversibly binding to 50S subunits of the ribosome. By this mechanism of action, macrolides are generally bacteriostatic agents. Their spectrum of activity includes mostly Gram-positive microorganisms, most Mycoplasma spp., some Chalmydiae as well as some Gram-negative pathogens such as Haemophilus influenzae, Campylobacter jejuni, Bordetella spp., Helicobacter pylori and Mannheimia haemolytica (Alvarez-Elcoro and Enzler 1999). Therefore, this class of antimicrobials has been important in the treatment of respiratory tract, skin, and soft tissue infections $\mathrm{H}$. pylori-induced acidity as well as venereal disease in man. In veterinary medicine, some macrolides (tilmicosin, tulathromycin) are also approved for the treatment of bronchopneumonia in cattle, Rhodococcus equi infections in foals and CRD in poultry.

Clarithromycin is a semi-synthetic antimicrobial agent that is derived from erythromycin (Rodvold 1999). This modification provides greater stability than erythromycin in gastric content, thus improving oral bioavailability.

Approved indications for the use of clarithromycin in man include the treatment of pharyngitis/tonsillitis due to Streptococcus pyogenes; acute maxillary sinusitis due to Haemophilus influenzae, Moraxella catarrhalis, or Streptococcus pneumoniae; community acquired pneumonia or bronchitis due to Haemophilus influenzae Mycoplasma pneumoniae, Streptococcus pneumoniae, Moraxella catarrhalis, or Chlamydia pneumoniae; uncomplicated skin infections due to Staphylococcus aureus, or Streptococcus pyogenes; disseminated mycobacterial infections due to Mycobacterium avium; and as a combined therapy with amoxicillin and a proton pump inhibitor for the treatment of gastric and duodenal ulceration caused by Helicobacter pylori.

Only a few pharmacokinetic and pharmacodynamic studies have been performed using clarithromycin in animals and no kinetic research has been carried out in poultry. Because of current unavailability of veterinary formulations of this macrolide, this study, therefore, has been performed to evaluate the pharmacokinetic parameters in broilers with the only commercialized formulation of clarithromycin for human use.

Following intravenous administration of clarithromycin in broilers at a dose of $7.5 \mathrm{mg} / \mathrm{kg}$ bw, no adverse effects or toxic manifestation was observed, just drowsiness for a few seconds. The overall mean of plasma concentration-time profile of clarithromycin following a $7.5 \mathrm{mg} / \mathrm{kg}$ b wt i.v. bolus dose in broilers is shown in Table 1 and Fig. 1.

The results revealed that plasma clarithromycin concentration versus time decreased in a bi-exponential manner, demonstrating the presence of distribution and elimination phases and fitting to the two-compartment open model. This finding is in agreement with that of clarithromycin in other species including foal (Womble et al. 2006), rat (Kohno et al. 1989) and man (Watkins and Klaassen 1986).
Table 2 report the overall mean for each PK parameter estimated for all studied birds after i.v. bolus administration. The drug was rapidly distributed with a short $\mathrm{T}^{1 / 2} \mathbf{2}_{\alpha}(0.38 \mathrm{~h}) . \mathrm{T}^{1 / 2} \mathbf{2}_{\alpha}$ is the time taken for the blood concentration of the drug to decline by $50 \%$ during the distribution phase of the disposition curve. Although there is no available data to compare them with $\mathrm{T}^{1} / 2_{\alpha}$ after i.v. injection, yet, this value may be inconsistent with that reported by (Abo-ElSooud et al. 2012) who found that $T^{1} / 2 \alpha$ for azithromycin (a macrolide related to clarithromycin) after its intravenous injection to broiler chickens is $0.10 \mathrm{~h}$.

The elimination half-life ( $\left.\mathrm{T}^{1 / 2} \mathrm{2}_{\beta}\right)$ was found to be $4.58 \mathrm{~h}$ in the present study. $T^{1 / 2}$ is the time taken for the blood concentration of the drug to decline by $50 \%$ during the elimination phase of the disposition curve. This result is shorter that that reported in foal for clarithromycin, $5.4 \mathrm{~h}$ (Womble et al. 2006); but seems longer than that reported for azithromycin $(3.05 \mathrm{~h}$ ) in broilers (Abo-El-Sooud et al. 2012).

The volume of distribution of a drug is a ratio of the amount of drug in the body at any time to the plasma concentration at that time. In a two-compartment model the volume of distribution changes after the administration of a dose, and at different times one of three volumes of distribution may hold, $\mathrm{V}_{\mathrm{c}}, \mathrm{V}_{\beta}$, and $\mathrm{V}_{\mathrm{d}(\mathrm{ss})}$. Among them the latter is the most reliable. At time zero the entire dose was contained within the central compartment and $V_{d}=V_{c}$. The drug then gradually distributes to the peripheral compartment $\left(\mathrm{V}_{\mathrm{t}}\right)$. As the physical volume through which the drug distributes increases, the volume of distribution increases. At steady state the loss of drug from elimination was matched exactly by the gain of drug from administration.

In the present study, the value of $\mathrm{V}_{\mathrm{d}(\mathrm{ss})}$ was found to be $(6.89 \mathrm{~L})$ indicated large extravascular distribution of the drug. Total blood volume in chicken is approximately $60 \mathrm{ml} / \mathrm{Kg}$ (Thrall et al. 2012), vis a chicken weighing $2.5 \mathrm{~kg}$ may have about $150 \mathrm{~mL}$ of blood. Nevertheless, this relatively large $V_{d}$ of clarithromycin was still smaller than that reported for clarithromycin in foal, $10.4 \mathrm{~L}$ (Womble et al. 2006); and azithromycin in broilers, $47.75 \mathrm{~L} / \mathrm{Kg}$ (Abo-El-Sooud et al. 2012) after i.v. administration. The unit used depends on whether the dose of the administered drug was calculated as absolute dose (in such case $\mathrm{L}$ is used as the unit for distribution) or in units of weight per weight, i.e. $\mathrm{mg} / \mathrm{Kg}$, (in such case $\mathrm{L} / \mathrm{Kg}$ is used to describe drug distribution).

Total clearance of a drug from the body is expressed in terms of the volume of blood cleared of the drug by the various elimination processes (biotransformation and excretion) per unit time and body weight. It represents the sum of all clearance processes. Therefore, it is a measure of the ability of the organs of elimination to remove drug from the plasma, and it is a constant of proportionality between the rate of elimination at any time and the corresponding plasma concentration. In the present study, the total body clearance of clarithromycin following i.v. administration was $1.2 \mathrm{~L} / \mathrm{h}$. The value may be close to that reported in foals, 1.27 $\mathrm{L} / \mathrm{h} / \mathrm{Kg}$ (Womble et al. 2006) but not to that in broilers, 0.77 $\mathrm{L} / \mathrm{h} / \mathrm{Kg}$ for azithromycin (Abo-El-Sooud et al. 2012).

Oral administration plasma concentration-time profiles of clarithromycin following a $7.5 \mathrm{mg} / \mathrm{kg} \mathrm{b}$ wt, i.c. bolus dose in broilers are shown in Table 1 and Fig. 5.

Table 3 report the overall mean for each pharmacokinetic parameter estimated for all studied birds after i.c. bolus administration. Following oral administration of clarithromycin to broilers at a dose of $7.5 \mathrm{mg} / \mathrm{Kg}$ bw, the drug was moderately rapidly absorbed with an intermediate absorption half-life $\mathrm{T}_{1 / 2(\mathrm{ab})}$ of $0.72 \mathrm{~h}$. This value was longer than that reported in foal, $0.59 \mathrm{~h}$ (Jacks et al. 2002); but shorter than that of desert tortoise, $8.47 \mathrm{~h}$ (Wimsatt et al. 1999); and man, 3.3h (Rodvold 1999).

Maximal plasma concentrations $\left(\mathrm{C}_{\max }\right)$ ranged from 1.41 to 1.89 $\mu \mathrm{g} / \mathrm{mL}$ with a mean $\mathrm{C}_{\max }$ of $1.69 \mu \mathrm{g} / \mathrm{mL}$. All animals reached maximal plasma concentration at time to peak ranging between 1.38 and $1.87 \mathrm{~h}$ with average of 1.69 hours after dosing $\left(\mathrm{T}_{\max }\right)$. These results, as expected, are inconsistent with values reported in foals (Jacks et al. 2002) and rats (Kohno et al. 1989) who found that clarithromycin reaches 0.92 and $2.6 \mathrm{mg} / \mathrm{L}$ after 2.5 and 2 hours, 
respectively. In a study conducted by (Chu et al. 1992a) in human administered escalating oral doses of clarithromycin (100 1200 $\mathrm{mg} / \mathrm{Kg} \mathrm{bw}$ ), $\mathrm{C}_{\max }$ was found to range between 0.35 and $3.97 \mathrm{mg} / \mathrm{L}$ after $\mathrm{T}_{\max }$ ranging between 1.46 and $2.2 \mathrm{~h}$. Data are also different from those of (Abo-El-Sooud et al. 2012) and (Peters et al. 1992) who found that clarithromycin-related drug that is azithromycin reaches 0.95 and $0.84 \mathrm{mg} / \mathrm{L}$ after 1.91 and 3 hours in broilers and human, respectively.

The elimination half-life of clarithromycin following i.c administration of $7.5 \mathrm{mg} / \mathrm{Kg}$ bw to broiler chickens was $2.11 \mathrm{~h}$ in the present study. This value is shorter than those reported in foals, $4.81 \mathrm{~h}$ (Jacks et al. 2002), desert tortoise $13.67 \mathrm{~h}$ (Wimsatt et al. 1999) and man, $2.27 \mathrm{~h}$ (Chu et al. 1992a).

The value of systemic bioavailability calculated in this study was $66.54 \%$, indicating good absorption of clarithromycin from oral administration site. Bioavailability is the amount or fraction $(F)$ in $\%$ of clarithromycin that reaches circulation intact after oral administration. It is determined by comparing the area under the plasma C-T curve following a single oral administration (AUC) in normal broiler chickens with that calculated following single intravenous injection (AUC) $)_{\text {iv }}$. This value was higher than those reported in foals, 57.3\% (Womble et al. 2006); man, 55\% (LeBel 1993), (Chu et al. 1992b); and for azithromycin in broilers $83.52 \%$ (Abo-El-Sooud et al. 2012).

High bioavailability of clarithromycin and maintenance of therapeutic concentration up to $12 \mathrm{~h}$ after oral administration suggests that the drug is suitable for oral administration for the treatment of systemic bacterial infections in broilers. This may be explained on the basis of protein binding capacity of clarithromycin that was found to be $52.46 \%$ in broilers' plasma in this study. This value of plasma protein binding capacity is lower than that recorded in man, which ranged between 66-75\% (LeBel 1993).

The plasma level of $\geq 0.2 \mu \mathrm{g} / \mathrm{ml}$ for clarithromycin is considered adequate against most sensitive bacteria which MIC equals or less than this value, including Streptococcus pneumoniae, Streptococcus pyrogenes, Moroxella catarrhalis, Haempphilus influnezae, Legionella pneumophila, Helicobacter pylori, Mycoplasma spp., Chlamydia spp, Clostridia spp., Mycobacteria spp. (Bahal and Nahata 1992).

\section{Conclusion}

It could be concluded that the disposition of clarithromycin after intravenous administration of $7.5 \mathrm{mg} / \mathrm{Kg}$ bw, to broiler chickens is best described by a bi-exponential regression and best fit to twocompartment open model. Bioavailability after oral administration was found about $66 \%$ and adequate drug concentration was recorded up to $12 \mathrm{~h}$ post administration with plasma protein binding capacity of $52 \%$. The study recommends the use of clarithromycin in broilers because of its good pharmacokinetic profile.

\section{Acknowledgement}

The authors would like to thank Dr. Othman El-Mahmoudy, Methodology \& Stability Section, Research \& Development Department, Sigma Pharmaceutical Co., Quesna, Egypt, for kind gifting Clarithromycin standard powder.

\section{References}

[1] Abo-El-Sooud K, Fahmy E, Afifi N \& El-Aty AA 2012, Pharmacokinetics and bioavailability of azithromycin following intramuscular and oral administrations in broiler chickens. Research Reviews in Biosciences 6, 264-270.

[2] Alvarez-Elcoro S \& Enzler MJ 1999, the macrolides: erythromycin, clarithromycin, and azithromycin. In: Mayo Clinic Proceedings: Elsevier. P 613-634.

[3] Amini H \& Ahmadiani A 2005, Sensitive determination of clarithromycin in human plasma by high-performance liquid chromatography with spectrophotometric detection. Journal of Chromatog- raphy B Analytical Technologies in the Biomedical and Life Sciences 817 ,
http://dx.doi.org/10.1016/j.jchromb.2004.12.003.

[4] Baggot J 1995, Pharmacokinetics: disposition and fate of drugs in the body. Veterinary pharmacology and therapeutics 18-52.

[5] Baggot JD 1977, Principles of drug disposition in domestic animals: the basis of veterinary clinical pharmacology: WB Saunders.

[6] Baggot JD 1978a, some aspects of clinical pharmacokinetics in veterinary medicine II. Journal of Veterinary Pharmacology and Therapeutics 1, 111-118. http://dx.doi.org/10.1111/j.13652885.1978.tb00314.x.

[7] Baggot JD 1978b, some aspects of clinical pharmacokinetics in veterinary medicine. I. Journal of Veterinary Pharmacology and Therapeutics $1, \quad 5-18 . \quad$ http://dx.doi.org/10.1111/j.13652885.1978.tb00300.x.

[8] Bahal N \& Nahata MC 1992, the new macrolide antibiotics: azithromycin, clarithromycin, dirithromycin, and roxithromycin. Annals of Pharmacotherapy 26, 46-55.

[9] Chu S, Sennello L, Bunnell S, Varga L, Wilson D \& Sonders R 1992a, Pharmacokinetics of clarithromycin, a new macrolide, after single ascending oral doses. Antimicrobial Agents and Chemotherapy 36, 2447-2453. http://dx.doi.org/10.1128/AAC.36.11.2447.

[10] Chu SY, Deaton R \& Cavanaugh J 1992b, Absolute bioavailability of clarithromycin after oral administration in humans. Antimicrobial Agents and Chemotherapy 36, 1147-1150. http://dx.doi.org/10.1128/AAC.36.5.1147.

[11] Craig W \& Suh B 1991, Protein binding and the antimicrobial effects: methods for the determination of protein binding. Antibiotics in laboratory medicine Williams \& Wilkins, Baltimore, Md $367-$ 402.

[12] Dorrestein GM 1991, the pharmacokinetics of avian therapeutics. Veterinary Clinics of North America: Small Animal Practice 21, 1241-1264. http://dx.doi.org/10.1016/S0195-5616(91)50135-2.

[13] Ferrero J, Bopp B, Marsh K, Quigley S, Johnson M, Anderson D, Lamm J, Tolman K, Sanders S \& Cavanaugh J 1990, Metabolism and disposition of clarithromycin in man. Drug Metabolism and Disposition 18, 441-446.

[14] Grizzle JE 1965, the two-period change-over design and its use in clinical trials. Biometrics 467-480 http://dx.doi.org/10.2307/2528104.

[15] Jacks S, Giguere S, Gronwall R, Brown M \& Merritt K 2002, Disposition of oral clarithromycin in foals. Journal of Veterinary Pharmacology and Therapeutics 25, 359-362. http://dx.doi.org/10.1046/j.1365-2885.2002.00420.x.

[16] Katayama M, Nishijima N, Okamura Y, Katayama R, Yamashita T, Kamishina H \& Uzuka Y 2012, Interaction of clarithromycin with cyclosporine in cats: pharmacokinetic study and case report. Journal of feline medicine and surgery 14, 257-261. http://dx.doi.org/10.1177/1098612X11435612.

[17] Kohno Y, Yoshida H, Suwa T \& Suga T 1989, Comparative pharmacokinetics of clarithromycin (TE-031), a new macrolide antibiotic, and erythromycin in rats. Antimicrobial Agents and Chemotherapy 33, 751-756. http://dx.doi.org/10.1128/AAC.33.5.751.

[18] LeBel M 1993, Pharmacokinetic properties of clarithromycin: a comparison with erythromycin and azithromycin. The Canadian Journal of Infectious Diseases 4, 148.

[19] Peters DH, Friedel HA \& McTavish D 1992, Azithromycin. Drugs 44, 750-799. http://dx.doi.org/10.2165/00003495-19924405000007.

[20] Riegelman S, Loo J \& Rowland M 1968, Concept of a volume of distribution and possible errors in evaluation of this parameter. Journal of Pharmaceutical Sciences 57, 128-133. http://dx.doi.org/10.1002/jps.2600570125.

[21] Riggs DS 1964, the Mathematical Approach to Physiological Problems. Academic Medicine 39, 235.

[22] Rodvold KA 1999, Clinical pharmacokinetics of clarithromycin. Clinical Pharmacokinetics 37, 385-398. http://dx.doi.org/10.2165/00003088-199937050-00003.

[23] Rosenbaum SE 2012, Basic pharmacokinetics and pharmacodynamics: An integrated textbook and computer simulations: John Wiley \& Sons.

[24] Thrall MA, Weiser G, Allison R \& Campbell TW 2012, Veterinary hematology and clinical chemistry: John Wiley \& Sons.

[25] Traunmuller F, Zeitlinger M, Zeleny P, Muller M \& Joukhadar C 2007, Pharmacokinetics of single- and multiple-dose oral clarithromycin in soft tissues determined by microdialysis. Antimicrobial Agents and Chemotherapy 51, 3185-3189. http://dx.doi.org/10.1128/AAC.00532-07. 
[26] Watkins J \& Klaassen CD 1986, Xenobiotic biotransformation in livestock: comparison to other species commonly used in toxicity testing. Journal of Animal Science 63, 933-942.

[27] Wimsatt J, Johnson J, Mangone BA, Tothill A, Childs JM \& Peloquin CA 1999, Clarithromycin pharmacokinetics in the desert tortoise (Gopherus agassizii). Journal of Zoo and Wildlife Medicine $36-43$.

[28] Womble AY, Giguère S, Lee EA \& Vickroy TW 2006, Pharmacokinetics of clarithromycin and concentrations in body fluids and bronchoalveolar cells of foals. American Journal of Veterinary Research 67, 1681-1686. http://dx.doi.org/10.2460/ajvr.67.10.1681.

[29] Zhang X, Zou M, Li S, Chen X \& Zhong D 2008, Bioavailability of clarithromycin cyclodextrin ternary complexes upon oral administration to healthy beagle dogs. Drug Development and Industrial Pharmacy 34, 1048-1053. http://dx.doi.org/10.1080/03639040801937474. 